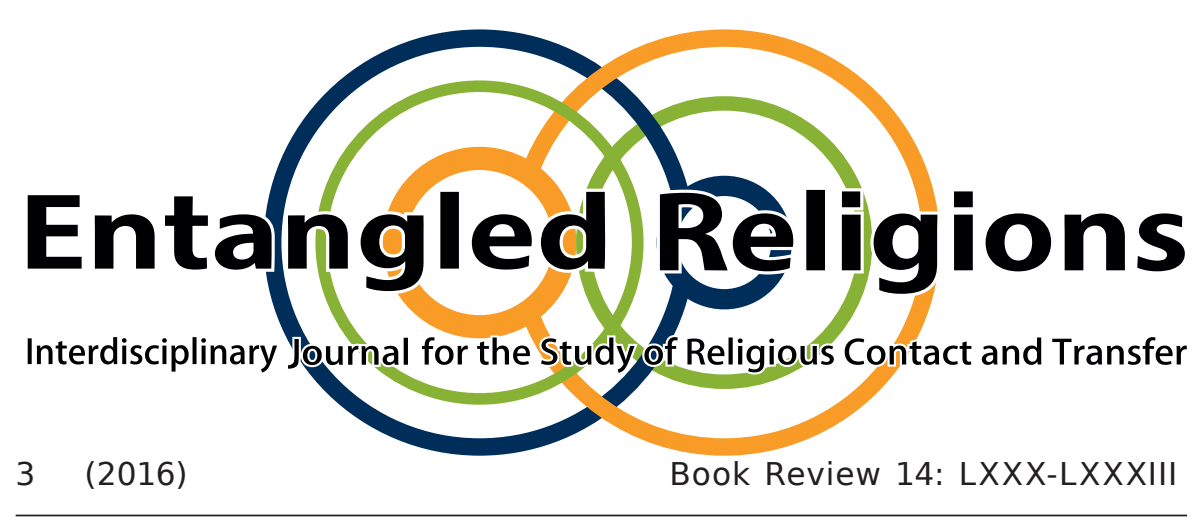

At the Intersection of Texts and Material Finds

Stepped Pools, Stone Vessels, and Ritual Purity

Among the Jews of Roman Galilee.

Göttingen: Vandenhoeck \& Ruprecht, 2015.

423 pages with 22 fig., € 140, ISBN 9783525550694

STUART S. MILLER

License:

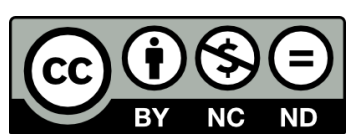

This contribution to Entangled Religions is published under the Creative Commons Attribution-NonCommercial-NoDerivatives 4.0 International Public License (CC BY-NC-ND 4.0 International). The license can be accessed at http://creativecommons.org/licenses/ by-nc-nd/4.0/ or is available from Creative Commons, 559 Nathan Abbot Way, Stanford, California 94305, USA.

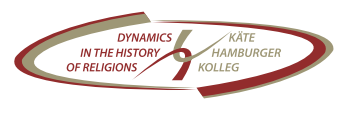

SPONSORED BY THE 


\title{
At the Intersection of Texts and Material Finds
}

\author{
Stepped Pools, Stone Vessels, and Ritual Purity \\ Among the Jews of Roman Galilee \\ Göttingen: Vandenhoeck \& Ruprecht, 2015.
}

423 pages with 22 fig., $€$ 140, ISBN 9783525550694

STUART S. MILLER

Scholars of ancient Judaism and the Bible are increasingly vexed by the problem of how to correlate archeological discoveries with the textual record. Whether we focus on Israel's early history, the Second Temple period, or Late Antiquity, the hopes of earlier historians to prove or disprove the accounts in ancient literature have given way to widespread puzzlement at material finds that paint very different pictures of Jewish life than do ancient texts portraying these periods. The history of scholarship has vacillated between, on the one hand, interpreting every archeological find against biblical, apocryphal and rabbinic literature and, on the other hand, refusing to consult the ancient texts at all to interpret material finds.

Stuart Miller engages this methodological problem with a detailed and nuanced discussion of the material and textual evidence for Jewish practices of ritual purification in water in the late Second Temple period and Late Antiquity. Eight hundred and fifty stepped pools from these periods have been found carved into bedrock in Judea and Galilee. Discussions of water purification appear among the Dead Sea Scrolls as well as in rabbinic literature, thus providing contemporary textual evidence for the phenomenon from two different Jewish sects, both of whom explicitly 
presuppose the older bathing requirements of the Hebrew Bible. So we have textual discussions of ritual bathing from three different ancient social settings as well as similar pools found in many different archeological sites. This plethora of evidence therefore offers ideal circumstances for exploring the methodological problem of how to relate material culture, ritual practice, and religious ideas.

Miller engages this evidence in eleven wide-ranging chapters which provide detailed discussions of the pools, especially those found in Sepphoris in Galilee dating throughout the Roman period, and of rabbinic discussions about how to guarantee the purity of the water for ritual baths. Miller argues that the pools found by archeologists should not necessarily be regarded as rabbinic miqvehs, but neither should they be considered completely distinct from rabbinic concerns. Instead, the pools and rabbinic discussions about water purity should both be understood as reflecting common Jewish concerns for maintaining purity as demanded by the Torah. This broader view of the topic leads him to analyze other kinds of evidence as well, such as the discussion about pools and purity in a Christian third or fourth century parchment found in Oxrhynchus, Egypt (P. Oxy. 840), and the prevalence of stone water jars in late Second Temple Judea. The latter have often been interpreted, like the stepped pools, as reflecting increasing Jewish concern for ritual purity in this period. Miller argues that, while that was likely the case, the use and disuse of particular instruments such as stone jars also reflected prevailing economic conditions, such as the stone carving industry stimulated by Herodian building projects in the first century which collapsed after the Jewish rebellions against Rome. Miller also devotes a chapter to setting Jewish water symbolism into its larger ancient Near Eastern and Hellenistic cultural contexts. 
Miller's study is notable for his judicious balancing of various kinds of evidence to paint a subtle picture of ancient Jewish ritual practices, their religious, economic and political causes, and the religious identities that they indexed. The price for addressing such mixed evidence is reflected in the structure of the book, which jumps back-and-forth between material finds and textual discussions in different periods and contexts. Nevertheless, Miller persuasively maintains his thesis throughout that ancient Jewish bathing practices reflected a common cultural concern for fulfilling the purity mandates in the Torah. This concern did not lessen and in fact may have strengthened after the destruction of the second Temple in 70 C.E. and the failure of the Bar Kochba revolt sixty-five years later. Material finds such as stepped pools and stone vessels, just like literary discussions in the Dead Sea scrolls and rabbinic literature, represent a sample of the various ways in which ancient Jews tried to live up to their responsibilities under the Torah.

JAMES W. WATTS

Syracuse University, USA 